\title{
LA-9107-MS
}
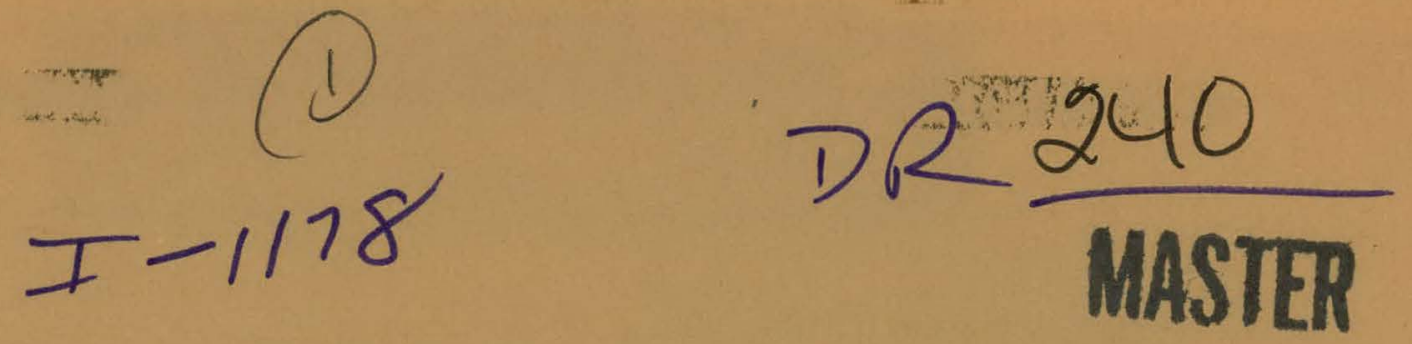

Los Alamos National I ahoratery is operated by the University of California for the United States Department of Energy under contract W-7405-ENG-36.

\section{Shipping Containers for Small Samples of High Explosives}

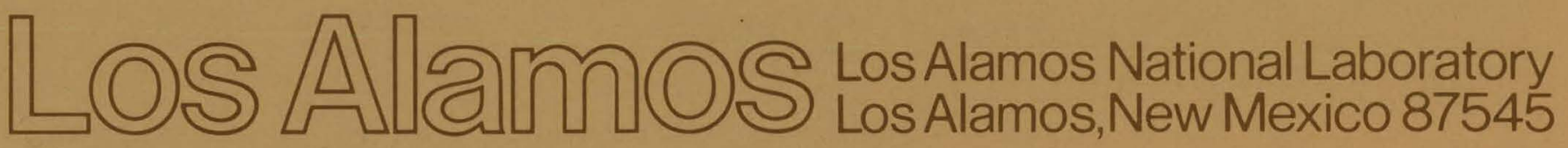




\section{DISCLAIMER}

This report was prepared as an account of work sponsored by an agency of the United States Government. Neither the United States Government nor any agency Thereof, nor any of their employees, makes any warranty, express or implied, or assumes any legal liability or responsibility for the accuracy, completeness, or usefulness of any information, apparatus, product, or process disclosed, or represents that its use would not infringe privately owned rights. Reference herein to any specific commercial product, process, or service by trade name, trademark, manufacturer, or otherwise does not necessarily constitute or imply its endorsement, recommendation, or favoring by the United States Government or any agency thereof. The views and opinions of authors expressed herein do not necessarily state or reflect those of the United States Government or any agency thereof. 


\section{DISCLAIMER}

Portions of this document may be illegible in electronic image products. Images are produced from the best available original document. 
Reviewed by R. Dreicer

\section{DISCLAIMER}

This report was prepared as an account of work sponsored by an agency of the United States Government. Neither the United States Government nor any agency thereof, nor any of their employees, makes any

warranty, express or implied, or assumes any legal liability or responsibility for the accuracy, completeness, or usefulness of any information, apparatus, product, or process disclosed, or represents that its use would not infringe privately owned rights. References herein to any specific commercial product, process, or service by trade name, trademark, manufacturer, or otherwise, does not necessarily constitute or imply its endorsement, recommendation, or favoring by the United States Government or any agency thereof. The views and opinions of authors expressed herein do not necessarily state or reflect those of the United States Government or any agency thereof. 
LA- $-9107-\mathrm{MS}$

DE82 010042

\title{
Shipping Containers for
}

\section{Small Samples of High Explosives}

\author{
Richard A. Hildner \\ Manuel J. Urizar
}


SHIPPING CONTAINERS FOR SMALL SAMPLES OF HIGH EXPLOSIVES

by

Richard A. Hildner and Manuel J. Urizar

\begin{abstract}
Two sizes of shipping containers for high explosives have been designed and tested at the Los Alamos National Laboratory. The containers have been tested by detonating a powerful, HMX-based explosive in the containers. The containers were approved for shipping 708 of the minimum weight of explosive that could cause vessel failure.
\end{abstract}

\title{
I. INTRODUCTION
}

In the explosives field, it is imperative that there be a method for shipping small quantities of explosives. These explosives may be uncharacterized materials sent for laboratory evaluation or standard explosives for test comparisons. In the past, small samples (up to $25 \mathrm{~g}$ ) have been shipped in steel pipes and have been classified as Class $C$ explosives. This is an unsafe practice, because the pipe could be shattered by detonation of the explosive.

The Los Alamos National Laboratory design criteria provide for safe shipment of high explosives by requiring containers capable of complete confinement of a possible detonation of the contents. The Lns Alamos containers use stand-off distance and absorption of the detonation energy to reduce the shock to the container walls to a level below the failure strength of the walls.

\section{CONTAINER DESIGN}

A cutaway view of a Los Alamos container is shown in Fig. 1 . The inner aluminum tube keeps the explosive away from the container walls and produces small, low-mass fragments if an explosion occurs. Vermiculite* is used as a filler around the inner tube to absorb explosion energy. The stainless steel outer cylinder wall absorbs the remaining energy by a rapid deformation. The container is shipped in a styrofoam-lined wooden box and the styrofoam prevents the container wall from reaching the box shell during expansion.

ॠVermiculite is any of a group of micaceous hydrated sillcates of different compositions. It is dehydrated for use as insulation. 
The outer wooden box ${ }^{*}$ is manufactured to meet Department of Transportation (DOT) specification No. $173.25^{\star *}$ The styrofoam liners are fabricated from $0.016 \mathrm{~g} / \mathrm{cm}\left(4.4 \mathrm{lb} / \mathrm{ft}^{3}\right)$ foam. The vessel end plugs are a modified $1 / 2-i n$. NPT stainless steel pipe plug and a 7/8-14 hex-head machine bolt. The stainless steel vessel is a modified Hoke DOT gas sampling bottle Model LD-1000 or Model LD-2250, depending on the size required. The vermiculite is insulation-grade No. 4, 60 mesh or $f$ iner. The inner aluminum tube is $1.91-\mathrm{cm}$ (3/4-in.)-o.d., 0.09-cm (0.035-in.)-wall 6061-T6 tubing. The components of the shipping vessel and the assembly are shown in Fig. 2. The Hoke vessel is modified for this use. One 1/2-in. NPT port is retapped to a standard 7/8-14 straight machine thread, and then the port threads on both ends of the vessel are relieved on the inside for $0.16 \mathrm{~cm}(1 / 16 \mathrm{in.})$. The length of the inner tube is measured between the bottoms of the thread reliefs, and the inner aluminum tube is cut to length. The inner tube is inserted from the bottom through the 7/8-14 port with the vessel in a vertical position. Vermiculite is added around the inner tube and lightly tamped until the space is filled. The inner tube is now worked up from the bottom until it seats on the bottom of the thread relief area of the $1 / 2-i n$. NPT port. The vessel is turned over and the inner tube is swaged into the thread relief on the 7/8-14 end using a $10^{\circ}$ tapered punch. The vessel is again turned over, and the inner tube is expanded to the diameter of the thread relief on the $1 / 2$-in NPT port. This completes the assembly. Figure 2 shows the components and assembly of the closure plugs. A standard 7/8-14 machine bolt is modified to receive the hollow, vermiculite-filled absorber cap, and the assemblies are rolled together. A standard 1/2-in. NPT pipe plug is modified by bolting an adapter stud to the plug and roliing a vermiculitefilled absorber cap in place. The finished vessels are shown in Fig. 3 .

\section{TEST RESULTS}

Five-gram pellets of $\mathrm{PBX} 9404,{ }^{\dagger} 1.59 \mathrm{~cm}(5 / 8 \mathrm{in.})$ in diameter by $1.27 \mathrm{~cm}$ (1/2 in.) long, were pressed to a density of about $1.7 \mathrm{~g} / \mathrm{cm}^{3}$ for use in the firing tests of the vessels. The ex-

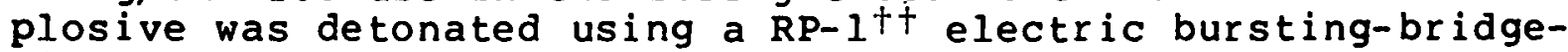
wire detonator. The leads for the detonator were threaded through a 7/8-14 machine bolt with a $0.48-\mathrm{cm}$ (3/16-in.)-diam hole through it and the bolt was used to close one end of the vessel. The test setup is shown in Fig. 4 .

\footnotetext{
*The box shown in Fig. I was not made to DOT specifications. It was used for testing only.

${ }^{\star *}$ Graziano's Tariff, Bureau of Explosives. +PBX 9404 is $94 / 3 / 3$ wtz $\mathrm{HMX} / \mathrm{nitrocellulose/tris(B-chloroethyl)-}$ phosphate.

†+Sold by Reynolds Industries Inc., P. O. Box 1170, Marina Del 2

Rey, California 90291.
} 
The minimum weight of detonating explosive that caused failure of the test vessels was determined. The LD-1000 vessel failed with the detonation of a minimum of $26 \mathrm{~g}$ of PBX 9404; the LD- 2500 vessel failed at a minimum of $40 \mathrm{~g}$ of the same explosive. The LD-1000 was rated acceptable for shipping $15 \mathrm{~g}$ of explosive; the LD-2500 vessel was rated acceptable for shipping $25 \mathrm{~g}$ of explosive.

The vessels were then tested with these explosive weight limits. After these tests, the vessels were sawed apart and examined to verify that the diameter and the wall thinning at the bulge were uniform, as shown in Figs. 5 and 6 , and to verify that the calculated strains were less than published yield values. The vessels were tested at ambient temperature only. Stainless steel does not exhibit any significant loss of ductility or strength at any of the temperatures the containers would encounter during transportation and handling. High temperatures, such as those in a fire, would decompose the explosive before any great strength loss in the container. The $7 / 8-14$ port is not gastight, so gases would be vented before high internal pressures could occur.

\section{CONCLUSION}

Group WX-2 has designed and tested shipping containers of two sizes that will ensure safety of the shipment of up to $15-\mathrm{g}$ or 25-g samples of any high explosive. These containers can be used safely for any shipping classification of explosives. Therefore, the problems and costs in the shipment of small samples of explosives are greatly reduced. 


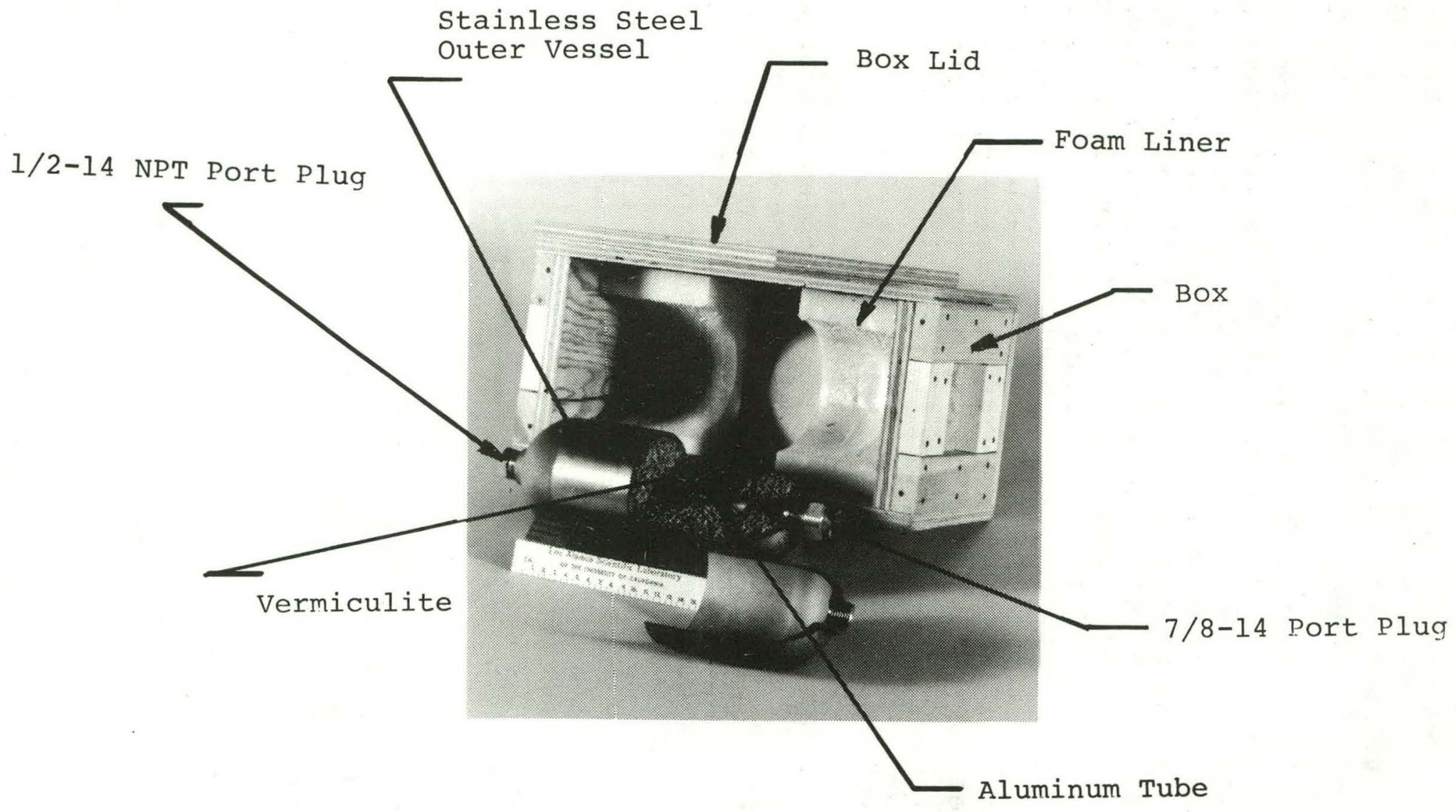

Fig. 1. Cut Away View of Shipping Container and Box. 


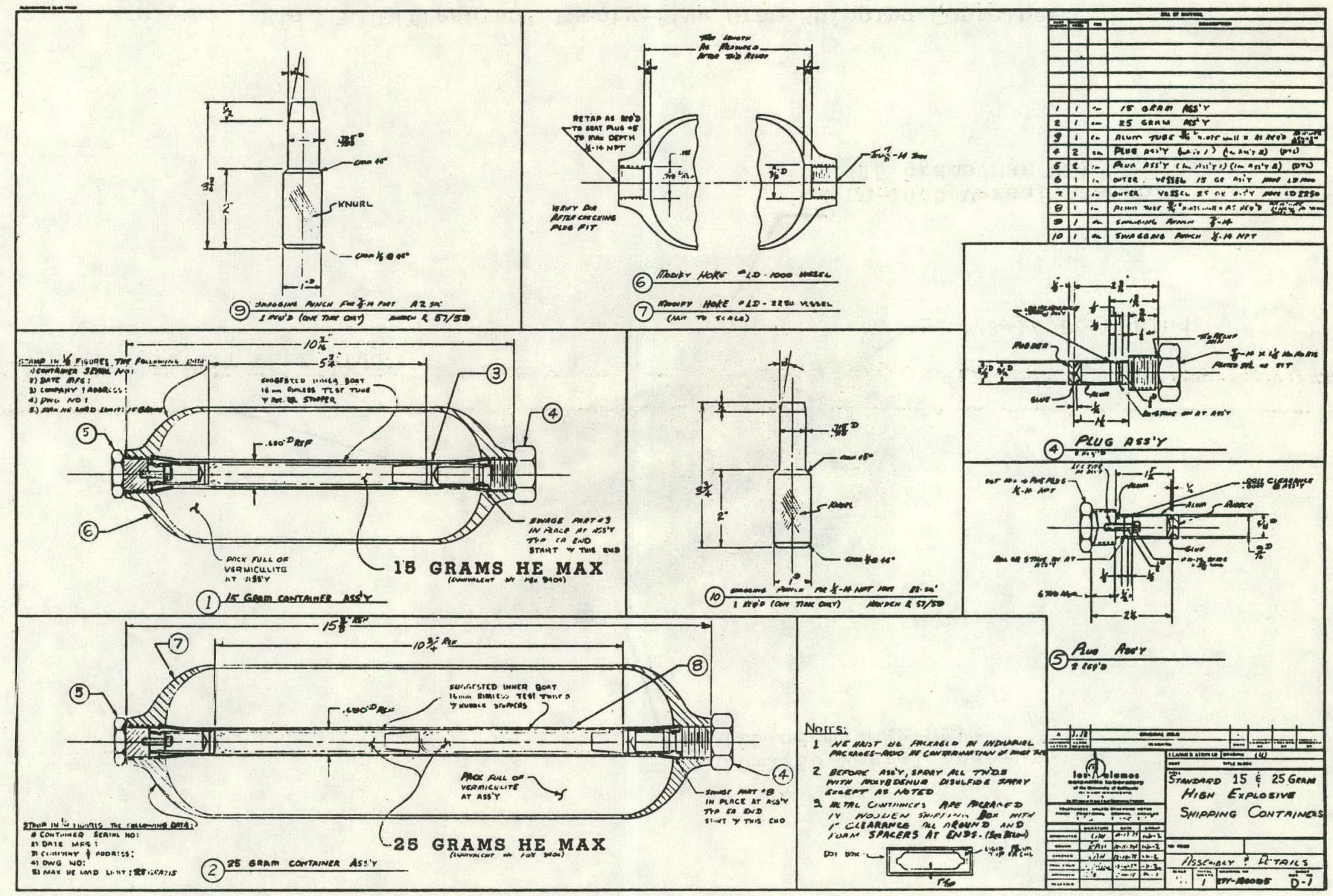

Fig. 2. Shop Drawing of Shipping Container. 


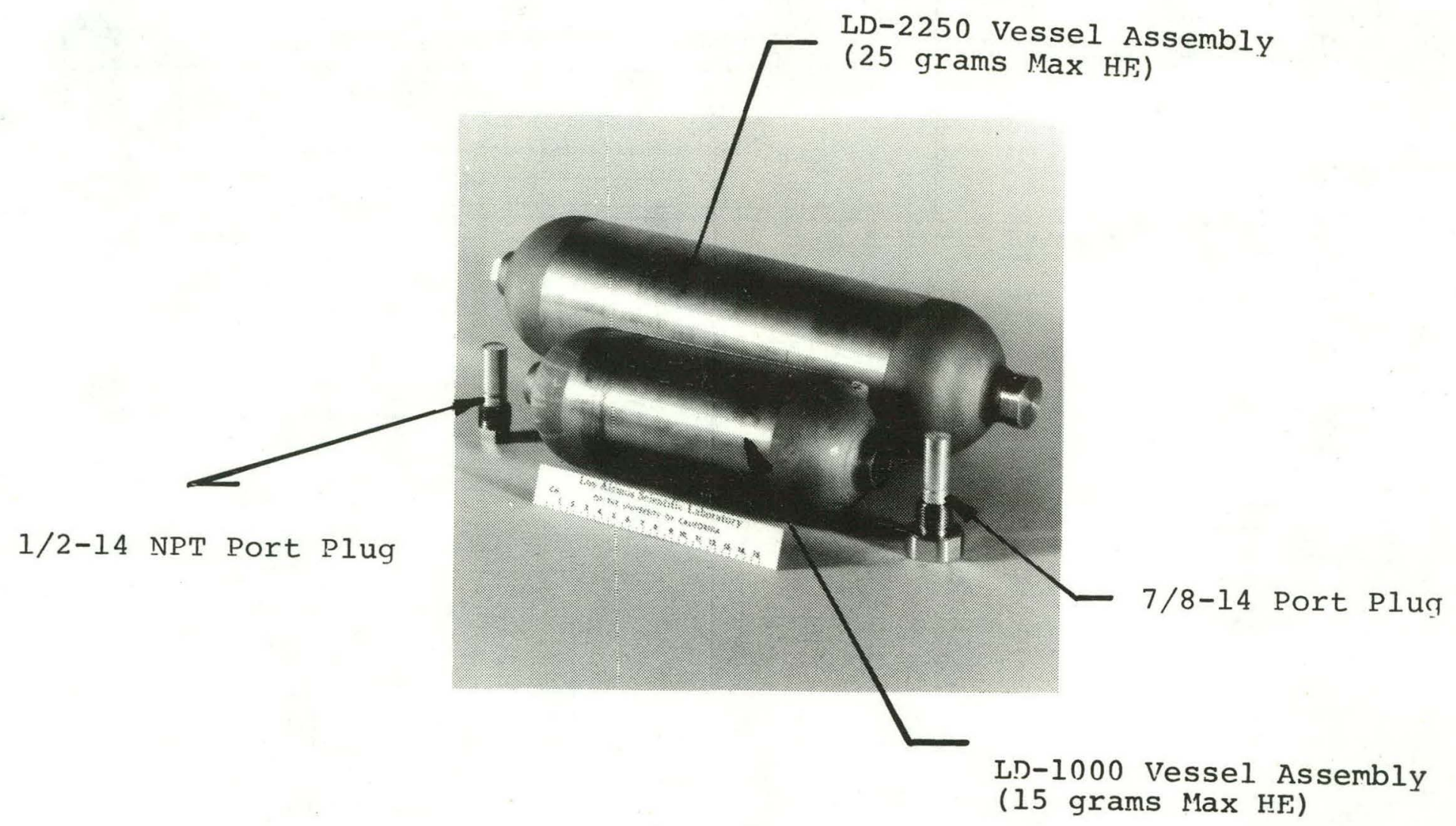

Fig. 3. Fifteen and Twenty-five Gram Shipping Container. 


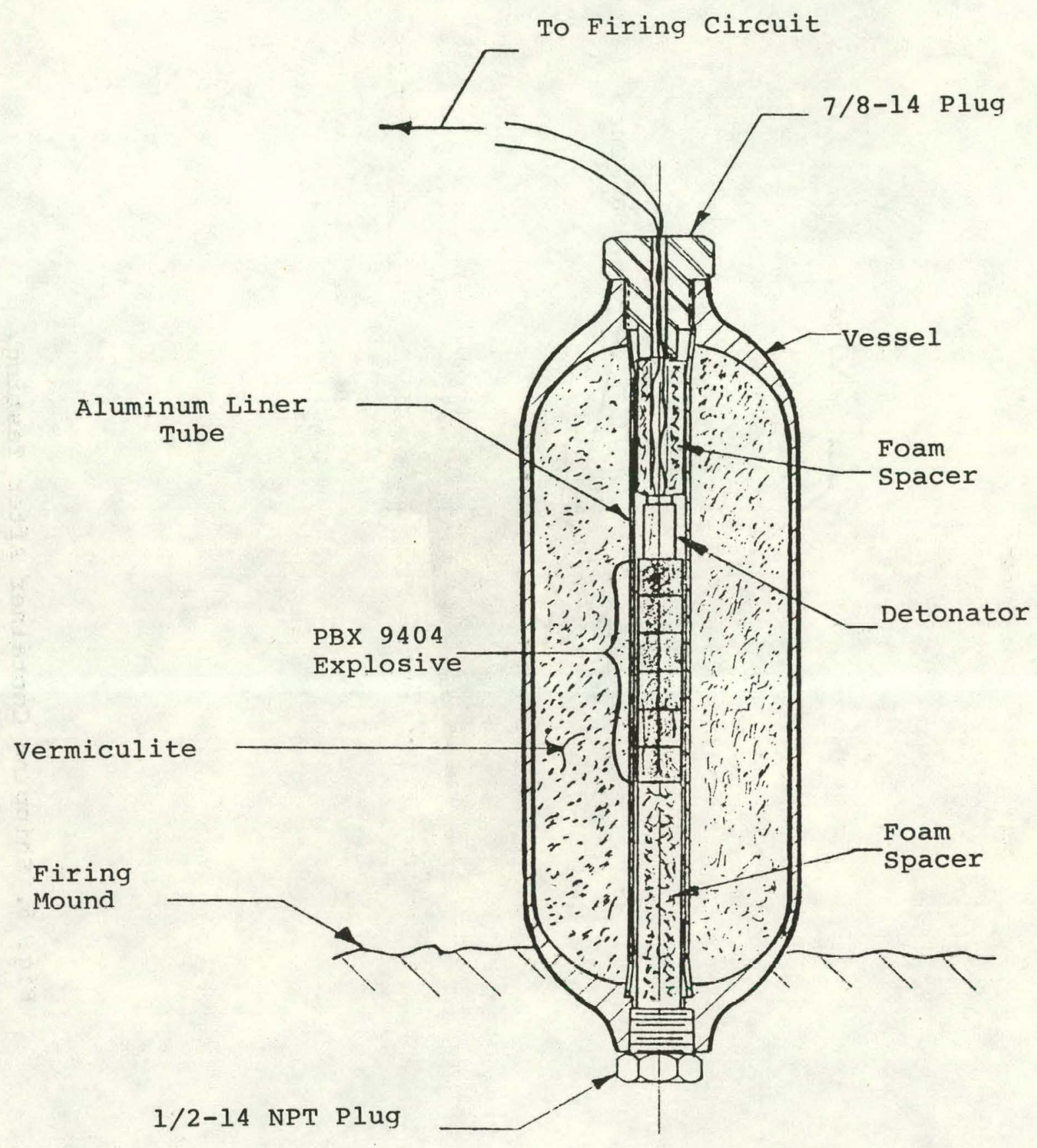

Fig. 4. Testing Configuration of Shipping Container. 


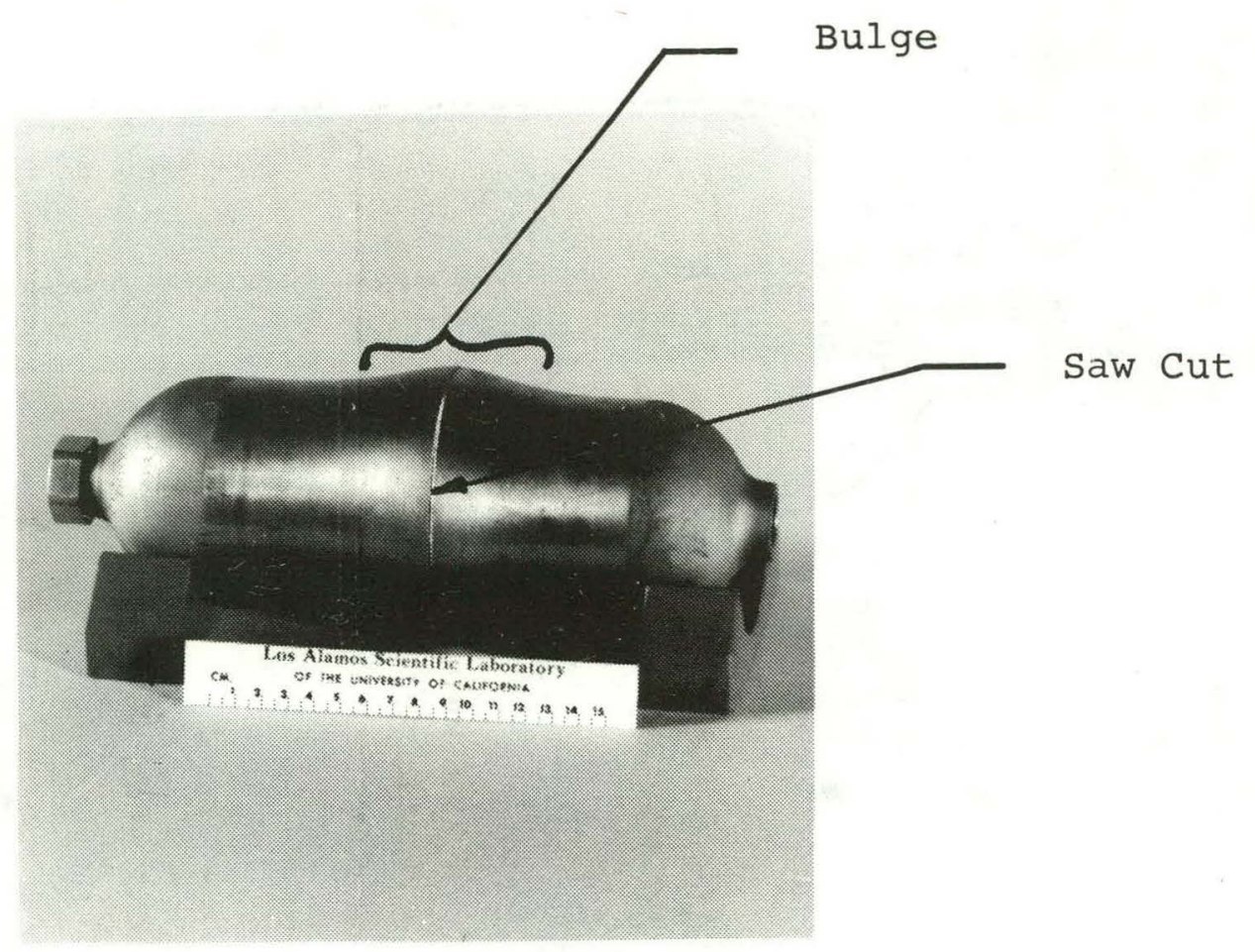

Fig. 5. Shipping Container After Testing. 


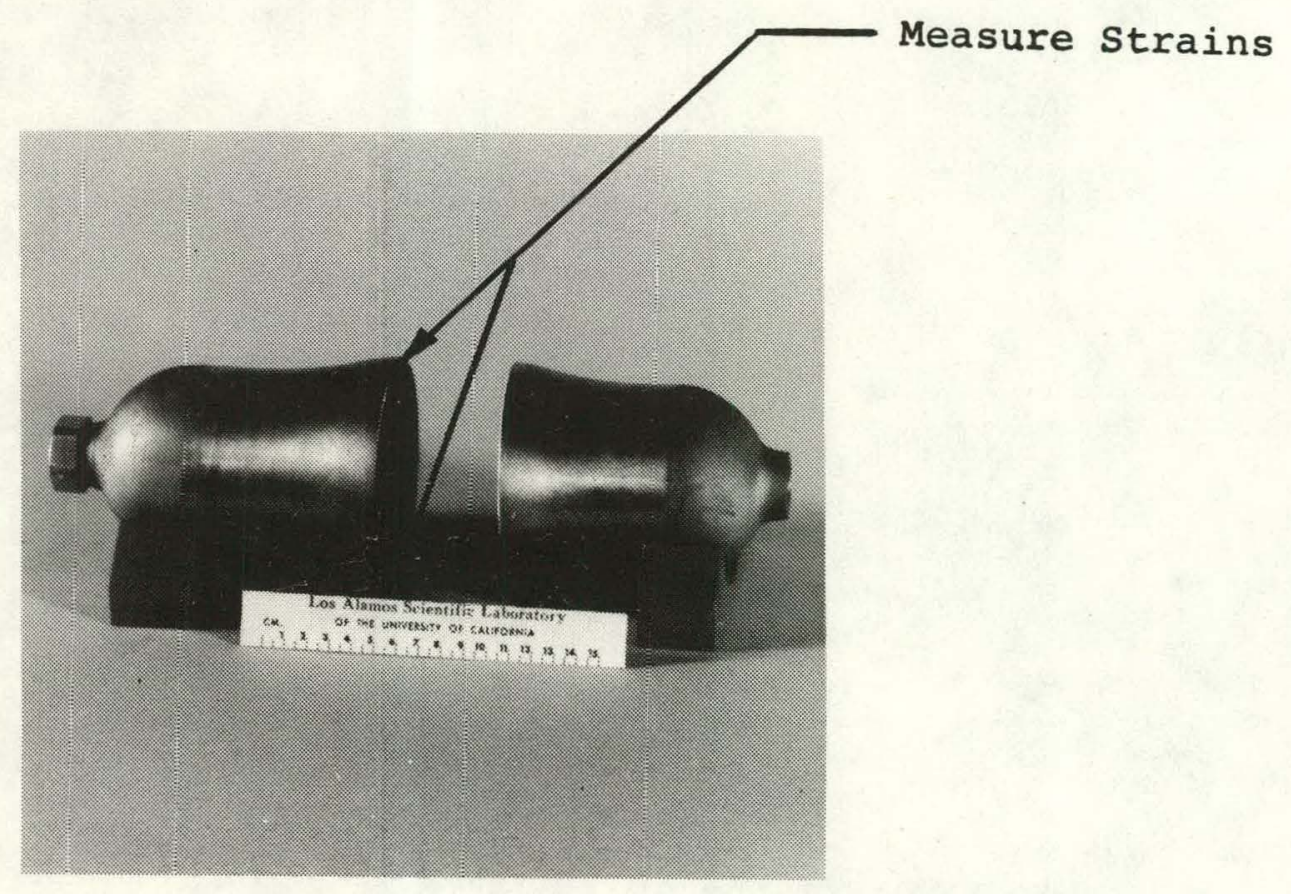

Fig. 6. Shipping Container After Testing. 


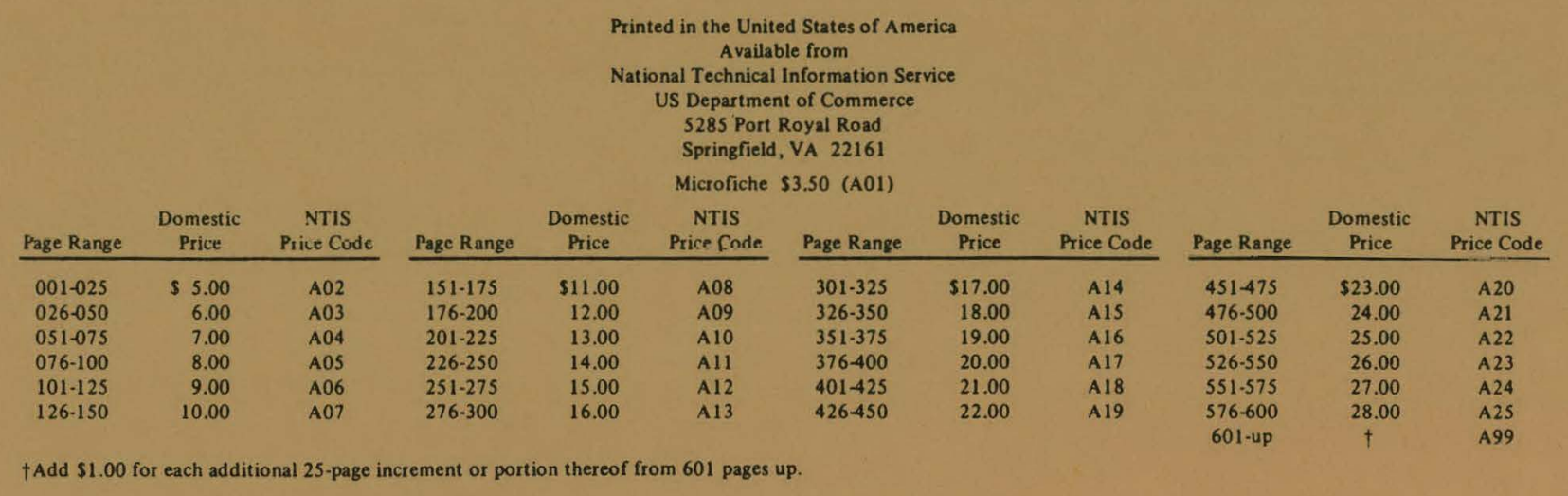


LOS Alaños 